\title{
ІІляхи профілактики тромбоемболічних ускладнень у травматологічних хворих
}

\begin{abstract}
Мета роботи: проаналізувати ефективність профілактики тромбоемболічних ускладнень у травматологічних хворих, які перенесли операційні втручання.

Матеріали і методи. Обстежували пацієнтів травматологічного відділення Тернопільської міської комунальної лікарні швидкої допомоги. У 2016 р. госпіталізовано 1410 хворих різних вікових категорій, які були поділені на 3 групи. Першу групу - 263 чоловіки (18,6 \%) - склали хворі із політравмою та несприятливим прогнозом для життя через тяжкість захворювання. У другу групу входили пацієнти із поєднаною травмою - 462 хворих (32,8 \%) - із сумнівним прогнозом для життя. Третя група - 685 пацієнтів (48,6 \%) - хворі з ізольованою травмою і сприятливими наслідками лікування. Усім пацієнтам, крім загальноклінічних обстежень, визначали кількість тромбоцитів, час згортання крові, тривалість кровотечі і в усіх вивчали коагулограму (протромбіновий індекс, протромбінову активність, тромботест, загальний фібриноген, фібриноген В, фібриноген А, активований час рекальцифікації). Стан венозної системи нижніх кінцівок досліджували за допомогою дистальної висхідної флебографії, кольорової доплерографії і дуплексної ультрасонографії апаратом SIMENS ACUSSON X 300.

Результати досліджень та їх обговорення. Усім хворим у повному об'ємі було проведено профілактику тромбоемболічних ускладнень шляхом застосування антикоагулянтів із низькою молекулярною масою і обов’язковим комплексом кінетерапії. Цибор у лікувальній дозі призначали з 1-ї доби перебування пацієнта в стаціонарі до 10-14-ї доби післяопераційного періоду один раз на добу підшкірно в ділянку живота. Для пацієнтів із помірним ризиком та високим операційним ризиком (великі втручання, вік, старший 40 років, ожиріння, серйозні супутні захворювання) цибор призначали по 5000-7500 МО на добу протягом перебування пацієнта в стаціонарі. При підозрі чи наявності змін з боку венозного русла ніг у хворих із обтяженим анамнезом проводили одягання еластичних панчіх та еластичне бинтування. Субопераційні рухи у гомілковостопних суглобах, рання активізація хворого після операції, лікувальна фізкультура здійснювались у всіх пацієнтів. Венотоніки (детралекс, флебодію та ін.) застосовували у комплексному лікуванні пацієнтів із хронічною венозною недостатністю. В осіб із підгострим і хронічним тромбофлебітом підшкірних вен здійснювали хірургічну профілактику тромбоемболічних ускладнень. Кросектомію виконано у 9 (1,9 \%) пацієнтів як перший етап перед операційним втручанням.
\end{abstract}

Ключові слова: тромбоемболізм; травматизм; профілактика.

Постановка проблеми і аналіз останніх досліджень та публікацій. Тромбоемболізм є одним із найбільш грізних ускладнень після операційних втручань, які зумовлюють високу летальність.

Частота тромбоемболізму перебуває в залежності від тривалості, травматичності втручань і, за даними більшості авторів, зростає із збільшенням об’єму операцій, розширенням показань до них, особливо у пацієнтів старечого та похилого віку [1]. Особливо загрозливим є стан справ у травматологічних та ортопедичних відділеннях, де тромбоемболічні ускладнення відзначаються більш ніж у половини пацієнтів. [5]

Діагностика, лікування і прогнозування наслідків тромбоемболізму цієї категорії пацієнтів супроводжуються значними труднощами. Заслуговує уваги той факт, що найбільша кількість летальних випадків (до 75,4 \%) зафіксована не в день травми, а на 3-5-ту добу після неї або пізніше $[2,4]$. Етіологія тромбоемболізму має багатофакторний характер, серед чого важливе значення надається варикозному розширенню вен нижніх кінцівок, флеботромбозу вен малого таза, венозному застою в нижніх кінцівках, післяопераційним порушенням реологічних властивостей крові.

Вагомою причиною тромбоемболічних ускладнень $є$ реакція організму на операційну травму, яка супроводжується спазмом периферичних судин, гіперкоагуляцією та травмою судинної стінки, особливо при операціях на нижніх кінцівках, кульшовому суглобі і кістках тазового кільця $[6,7,8]$.

Флеботромбоз глибоких вен нижніх кінцівок і малого таза ускладнює перебіг післяопераційного періоду у 10-30 \% осіб старшої вікової групи [3].

У багатьох хворих першим клінічним проявом флеботромбозу глибоких вен може бути тромбоемболія легеневої артерії. 3 віком в організмі відбувається низка гемодинамічних (зменшується ударний і хвилинний обсяг та об’єм циркулюючої крові, зростає периферичний опір судин) і гематологічних змін (підвищується агрегаційно-адгезивна здатність тромбоцитів, активність плазмових факторів згортання, концентрація фібриногену), які сприяють виникненню флеботромбозу глибоких вен $[9,10]$. 
Мета роботи: проаналізувати ефективність профілактики тромбоемболічних ускладнень у травматологічних хворих, які перенесли операційні втручання.

Матеріали і методи. Обстежували пацієнтів травматологічного відділення Тернопільської міської комунальної лікарні швидкої допомоги. У 2016 р. госпіталізовано 1410 хворих різних вікових категорій. Чоловіків було 588 (41,7 \%), жінок $-822(58,3 \%)$.

У ході дослідження хворі були поділені на 3 групи залежно від тяжкості травми.

Першу групу - 263 пацієнти (18,6 \%) - склали хворі із політравмою та несприятливим прогнозом для життя через тяжкість захворювання.

У другу групу входили пацієнти із поєднаною травмою - 462 хворих (32,8 \%) - із сумнівним прогнозом для життя.

Третя група - 685 пацієнтів (48,6 \%) - хворі 3 ізольованою травмою і сприятливими наслідками лікування (рис. 1).

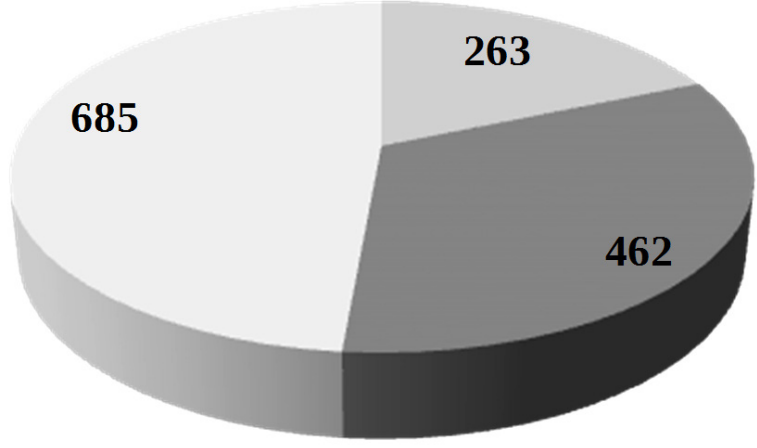

Рис. 1. Кількісна характеристика травматологічних хворих, які госпіталізовані в стаціонар.

Хворі першої групи госпіталізовані у стані тяжкого поєднаного шоку. Їм проводили реанімаційні заходи, спрямовані на корекцію гемодинаміки і функції зовнішнього дихання. Комплексне обстеження таких пацієнтів включало клініко-лабораторні та рентгенологічні методи, застосовували лапароцентез, торакоцентез, сонографію, комп’ютерну томографію.

При діагностуванні кровотечі, що триває, в ургентному порядку, на тлі протишокових заходів проводили хірургічні втручання, спрямовані на їі зупинку. На пошкоджені сегменти опорно-рухового апарату при задовільному стоянні відламків накладали гіпсові пов’язки та скелетний витяг при наявності зміщень.

У другій групі постраждалих лікування також розпочинали з операцій за життєвими показання- ми (боротьба з кровотечею, дихальною недостатністю). Всі заходи проводили на фоні інтенсивної протишокової терапії та ліквідації домінуючих пошкоджень внутрішніх органів після відповідної передопераційної підготовки. Надалі, при задовільних гемодинамічних показниках, здійснювали термінові операції з приводу травм опорнорухового апарату.

При операційних втручаннях у хворих третьої групи із тяжкою домінуючою травмою опорно-рухового апарата, серед яких виділяли переломи стегна, кісток гомілки, плеча, передпліччя, стопи, кисті, плечового пояса, віддавали перевагу металоостеосинтезу. Виняток складали випадки тяжких розміщень та відривів кінцівок. Таким пацієнтам в ургентному порядку проводили первинну хірургічну обробку рани або ампутацію кінцівки.

Усім пацієнтам, крім загальноклінічних обстежень, визначали кількість тромбоцитів, час згортання крові, тривалість кровотечі і в усіх вивчали коагулограму (протромбіновий індекс, протромбінову активність, тромботест, загальний фібриноген, фібриноген В, фібриноген А, активований час рекальцифікації).

Стан венозної системи нижніх кінцівок досліджували за допомогою дистальної висхідної флебографії, кольорової доплерографії і дуплексної ультрасонографії апаратом SIMENS ACUSSON X 300. Вивчали стан глибокої венозної системи: глибоку вену стегна, групу двочеревцевого венозного синуса, камбалоподібний венозний синус, загальну та поверхневу стегнові вени, підколінну, передню та задню великогомілкові вени. У системі поверхневих вен досліджували стегновий та колінний сегменти великої підшкірної вени, передню та задню додаткові підшкірні вени стегна, стегнопідколінну підшкірну вену, малу підшкірну вену, а також поверхнево - глибокі венозні співустя (сафено-феморальне та сафено-поплітеальне) і систему перфорантих вен, ступінь недостатності клапанів.

Супровідну патологію серцево-судинної, дихальної та ендокринної систем виявлено у 1167 (82,8 \%) осіб.

У пацієнтів із декомпенсацією супровідної патології (ішемічна хвороба серця, гіпертонічна хвороба, неспецифічні хронічні захворювання легень, цукровий діабет) проводили передопераційне приготування в умовах стаціонару.

Характер операційних втручань, проведених за період дослідження у відділенні: операцій всього - 865, у тому числі ургентних 410. Решту пацієнтів лікували консервативно (табл. 1). 
Таблиця 1. Характер операційних втручань, проведених у травматологічному відділенні

\begin{tabular}{|c|c|c|}
\hline Назва операції & Кількість & $\begin{array}{c}\text { Кількість тромбоемболічних } \\
\text { ускладнень }\end{array}$ \\
\hline \multicolumn{2}{|l|}{ 1. Операційні втручання на сегментах опорно-рухової системи: } & \multirow[b]{8}{*}{$10,0 \%$} \\
\hline 1.1. Відкрита репозиція та металоостеосинтез & 376 & \\
\hline 1.1.1. Інтрамедулярний блокуючий металоостеосинтез & 44 & \\
\hline 1.1.2. Апарати зовнішньої фіксації & 25 & \\
\hline 1.1.3. Репозиційний & 12 & \\
\hline 1.1.4. Накісними пластинами & 295 & \\
\hline 1.2. Первинна хірургічна обробка та металоостеосинтез & 74 & \\
\hline 1.3. Первинна хірургічна обробка без металоостеосинтезу & 191 & \\
\hline 2. Операції на суглобах & 93 & \multirow{5}{*}{$44,2 \%$} \\
\hline 2.1. Відкрита репозиція та металоостеосинтез & 38 & \\
\hline 2.2. Вилучення металофіксаторів & 3 & \\
\hline 2.3. Артроскопія & 3 & \\
\hline 2.4. Ендопротезування & 49 & \\
\hline 3. Реконструктивні операції & 31 & \multirow{3}{*}{$24,1 \%$} \\
\hline 3.1. На м’яких тканинах & 27 & \\
\hline 3.2. На кістках & 4 & \\
\hline 4. Видалення металоконструкцій & 56 & - \\
\hline 5. Малоінвазивні втручання & 19 & - \\
\hline 6. Паліативні втручання при метастатичному ураженні кісток & 12 & $4,5 \%$ \\
\hline 7. Інші & 10 & - \\
\hline
\end{tabular}

Результати досліджень та їх обговорення. В обстежених пацієнтів виділяли низку чинників виникнення післяопераційних тромботичних ускладнень: тромботичні ускладнення в анамнезі, порушення коагулограми, серцево-судинні та злоякісні захворювання, надмірну масу тіла, травматичні ускладнення, характер травми. Серед злоякісних захворювань найчастіше зустрічався рак молочної залози, рак простати та прямої кишки, які зумовили виникнення патологічних переломів стегнової та плечової кісток.

Хронічну серцеву недостатність I-II ст. діагностовано у 651 (46,2 \%) хворого, варикозне розширення підшкірних вен нижніх кінцівок - у 624 (42,2 \%) пацієнтів. Ожиріння констатовано у 237 (16,8 \%) хворих. Гіперкоагуляцію встановлено у 270 (18,2 \%) пацієнтів. Зміни у коагулограмі не завжди відповідали тяжкості й особливостям флеботромбозу. Лише у 6 із 33 хворих протягом 8 днів після операції появлявся фібриноген В. Незначне підвищення фібриногену А було зафіксовано у 22,3 \%, значне (до 9,9 г/л) - у 24,2 \% хворих. У всіх інших пацієнтів його вміст був зменшений до 1,45 г/л. Зміни інших показників не були суттєвими, що не викликало необхідності призначати додаткові інструментальні методи обстеження.

На варикозну хворобу нижніх кінцівок хворіли 752 пацієнти (53,3 \%). Сафенектомію перенесли 227 хворих (16,1%). Перенесений у минулому тромбофлебіт підшкірних або глибоких вен нижніх кінцівок виявлено у 72 (15,3 \%) осіб.

Вибір методу анестезії також впливав на кількість тромботичних ускладнень. Однією із основних причин тромбоемболічних ускладнень у травматологічних хворих у післяопераційному періоді є спазм периферичних судин, викликаний операційним стресом, що призводить до ішемії тканин і розвитку тромбозів. Стресова реакція організму при загальному знеболюванні є результатом недостатньої блокади нервових імпульсів, які передаються по симпатичній нервовій системі.

Кількість флеботромбозів у пацієнтів, оперованих під загальним знеболюванням із застосуванням штучної вентиляції легень, була високою і склала 22 випадки (68,3 \%). Зниження кількості ускладнень відбулося за рахунок значного зменшення стресових імпульсів при застосуванні спінальної анестезії (9 пацієнтів (27,2 \%)) та провідникової анестезії у комбінації із внутрішньовенним знеболюванням - 2 хворих (4,5 \%).

Профілактика тромботичних ускладнень була спрямована на ліквідацію таких патогенетичних ланок флеботромбозів, як сповільнений кровотік, підвищене згортання крові, пошкодження судинної стінки, і залежала від наявності факторів ризику.

За механізмом дії застосовували фізичні, медикаментозні та хірургічні методи профілактики 


\section{З ДОСВІДУ РОБОТИ}

тромбофлебітів нижніх кінцівок. За часом проведення ці методи застосовували доопераційно, субопераційно та післяопераційно.

Профілактичні засоби починали проводити на 1-2 добу перебування пацієнта в стаціонарі.

Усім хворим у повному об’ємі було проведено профілактику тромбоемболічних ускладнень шляхом застосування антикоагулянтів із низькою молекулярною масою та обов’язковим комплексом кінетерапії. Цибор у лікувальній дозі призначали з 1-ї доби перебування пацієнта в стаціонарі до 10-14-ї доби післяопераційного періоду один раз на добу підшкірно в ділянку живота. Для пацієнтів із помірним ризиком та високим операційним ризиком (великі втручання, вік, старший 40 років, ожиріння, серйозні супутні захворювання), цибор призначали по 5000-7500 МО на добу протягом перебування пацієнта в стаціонарі.

При підозрі чи наявності змін з боку венозного русла ніг у хворих із обтяженим анамнезом проводили одягання еластичних панчіх та еластичне бинтування.

Субопераційні рухи у гомілковостопних суглобах, рання активізація хворого після операції, лікувальна фізкультура здійснювались у всіх пацієнтів.

Венотоніки (детралекс, флебодію та ін.) застосовували у комплексному лікуванні пацієнтів із хронічною венозною недостатністю.

В осіб із підгострим і хронічним тромбофлебітом підшкірних вен здійснювали хірургічну профілактику тромбоемболічних ускладнень. Кросектомію виконано у 9 (1,9%) пацієнтів як перший етап перед операційним втручанням.

\section{СПИСОК ЛІТЕРАТУРИ}

1. Винник Ю. А. Профилактика тромбоэмболических осложнений у онкологических больных / Ю. А. Винник, Ю. Б. Волос, Ю. В. Шманько // Х з'їзд онкологів України : матеріали з'їзду. - К., 2001. - С. 268.

2. Роль гемодинамических нарушений в выборе тактики хирургического лечения пострадавших с сочетанной травмой груди и конечностей / Г. А. Гринцов, В. П. Танцюра, Р. Е. Песчаный, А. Г. Высокий // Вестник неотложной и восстановительной медицины. - 2011. - Т. 5, № 2. - С. 230-232. 3. Ефетова Т. С. Профилактика микроциркуляторных расстройств, вызванных операционной травмой и связанных с ними осложнений при радикальных операциях по поводу рака желудка / Т. С. Ефетова // Клінічна хірургія. - 2012. - № 8. - C. 37-41.

4. Мазуренко О. В. Аналіз летальності потерпілих з ізольованою та поєднаною травмою / О. В. Мазуренко, В. Ю. Кузьмін // Клінічна хірургія. - 2008. - № 12. - С. 21-23.

5. Стародубцева М. Б. Интенсивная терапия тромбоэмболии легочной артерии у онкологических больных с использова-
Незважаючи на комплекс профілактичних заходів, на 4-5 добу після операції у 10 хворих (1,1 \%) розвинувся тромбофлебіт варикозно розширених підшкірних вен гомілки, у 12 (1,3 \%) ілеофеморальний тромбоз, у 8 пацієнтів (0,9%) діагностовано тромбоз глибоких вен нижніх кінцівок. Медикаментозна терапія була ефективна у 16 осіб. 4 хворим виконано перев’язку великої підшкірної вени стегна. У одному випадку спостерігали ТЕЛА дрібних гілок. Не зафіксовано жодного летального випадку, пов'язаного із тромбоемболічними ускладненнями. Геморагічних ускладнень не було.

Таким чином, врахування патогенетичних механізмів розвитку тромбоемболічних ускладнень при призначенні комплексних заходів для їх профілактики дозволило зменшити відсоток післяопераційних ускладнень та летальності у травматологічних хворих.

Висновки. 1. У травматологічних хворих, які перенесли операційні втручання, визначається високий ризик тромбоемболічних ускладнень, що $є$ передумовою для проведення у них профілактичних заходів.

2. Профілактика тромбоемболічних ускладнень повинна бути комплексною та індивідуальною із врахуванням характеру травми та об’єму операційного втручання, супутніх чинників ризику їх виникнення.

3. Поєднання фізичних, медикаментозних та хірургічних засобів профілактики попереджувало виникнення тромбоемболічних ускладнень у травматологічних хворих.

нием фраксипарина / М. Б. Стародубцева, Е. Н. Демьяненко, Е. И. Шпаков // Х з'їзд онкологів України : матеріали з'їзду. - K., 2001. - С. 284-285.

6. Процик А. І. Принциповий підхід до надання медичної допомоги потерпілим з політравмою на догоспітальному етапі / А. І. Процик // Клінічна хірургія. - 2015. - № 4. - С. 28-29.

7. Савельев В. С. Профилактика послеоперационных венозных тромбоэмболических осложнений / В. С. Савельев // Российский консенсус. - М., 2010. - 20 с.

8. Оценка риска возникновения венозного тромбоза и эмболии у хирургических больных / В. Ф. Саенко, А. П. Мазур, В. В. Грубник // Клінічна хірургія. - 2003, № 8. - С. 5-8. 9. Kakkar A. K. Prevention of venosthromboembolism in cancer patient / R. C. N. Williamson, A. K. Kakkar // Semin. Thromb. Hemost. - 2009. - Vol. 25. - P. 239-243.

10. Prevention of venous thromboembolism. The seventh ACCP Conference on Antithrombotic and Thrombolytic Therapy / W. H. Geerts, G. F. Pineo, J. A. Heit [et al.] // CHEST. - 2004. Vol. 126. - P. 338-400. 


\section{REFERENCES}

1. Vinnik, Yu.A., Volos, Yu.B., \& Shmanko, Yu.V. (2001). Profilaktika tromboembolicheskikh oslozhneniy u onkologicheskikh bolnykh. [Prevention of thromboembolic complications in cancer patients]. $X$ zyizd onkolohiv Ukrainy: Materialy zizdu - X congress of oncologists of Ukraine: Materials of Congress. Kyiv [in Russian].

2. Grintsov, G.A., Tantsyura, V.P., Peschanyi, R.Ye., \& Vysokiy, A.G. (2011). Rol gemodinamicheskikh narusheniy v vybore taktiki khirurgicheskogo lecheniya postradavshikh s sochetannoy travmoy grudi i konechnostey [The role of hemodynamic disorders in the choice of tactics of surgical treatment of victims with combined trauma of the chest and limbs]. Vestnik neotlozhnoy i vosstanovitelnoy meditsiny - Journal of Emergency and Restorative Medicine, 5 (2), 230-232 [in Russian].

3. Yefetova, T.S. (2012). Profilaktika mikrotsirkulyatornykh rasstroystv, vyzvannykh operatsionnoy travmoy i svyazannykh s nimi oslozhneniy pri radikalnikh operatsyyakh po povodu raka zheludka [Prevention of microcirculatory disorders caused by operational trauma and associated complications in radical surgery for stomach cancer]. Klinichna khirurhiya - Clinical Surgery, 8, 37-41 [in Russian].

4. Mazurenko, O.V., \& Kuzmin V.Yu. (2008). Analiz letalnosti poterpilykh z izolovanoiu ta poiednanoiu travmoiu. [Analysis of mortality victims with isolated and combined trauma]. Klinichna khirurhiia - Clinical Surgery, 12, 21-23 [in Ukrainian].

5. Starodubtseva, M.B., Demyanenko, E.N., \& Shpakov, E.I.
(2001). Intensivnaya terapiya tromboembolii legochnoy arterii u onkologicheskikh bolnykh s ispolzovaniem fraksyparina [Intensive therapy of pulmonary embolism in cancer patients using fractiparin] $X$ ziizd onkolohiv Ukrainy: Materialy zizdu - X Congress of Oncologists of Ukraine: Materials of Congress. Kyiv [in Russian]. 6. Protsyk, A.I. (2015). Pryntsypovyi pidkhid do nadannia medychnoi dopomohy poterpilym z politravmoiu na dohospitalnomu etapi [The fundamental approach to providing medical care to victims of prehospital polytrauma]. Klinichna khirurhiia - Clinical Surgery, 4, 28-29 [in Ukrainian].

7. Savelyev, V.S. (2010). Profilaktika posleoperatsionnykh venoznikh tromboembolicheskikh oslozhneniy [Prevention of postoperative venous thromboembolic disorders] Rossiyskiy konsensus - The Russian Consensus, 20 [in Russian].

8. Sayenko V.F., Mazur A.P., Grubnik V.V., Fillipenko V.A, Kobza I.I., Popik M.P., Kalinin O.G., Krivoruchko I.A., \& Boyko V.V. (2003). Otsenka riska vozniknoveniya venoznogo tromboza i embolii u khirurgicheskikh bolnykh [Assessment of the risk of venous thrombosis and embolism in surgical patients]. Klinichna khirurhiia - Clinical Surgery, 8, 5-8 [in Russian].

9. Kakkar, A.K., \& Williamson, R.C.N. (2009). Prevention of venos thromboembolism in cancer patient. Semin. Thromb. Hemost., 25, 239-243.

10. Geerts, W.H., Pineo, G.F., \& Heit, J.A. (2004). Prevention of venous thromboembolism. The Seventh ACCP Conference on Antithrombotic and Thrombolytic Therapy. CHEST, 126, 338-400.

\section{YU. IVASHCHUK ${ }^{1}$, D. V. OSADCHUK ${ }^{1}$, B. M. MAYKA ${ }^{2}$}

I. Horbachevsky Ternopil State Medical University ${ }^{1}$, Ternopil City Municipal Emergency Hospital ${ }^{2}$

\section{WAYS OF PREVENTION OF THROMBOEMBOLIC COMPLICATIONS IN TRAUMA PATIENTS}

The aim of the work: to analyze the prevention of thromboembolic complications in trauma patients who underwent surgery. Materials and Methods. Patients were examined in the Traumatology Department of Ternopil City Municipal Emergency Hospital. In 20161410 patients of different ages, who were divided into 3 groups had been hospitalized. The first group - 263 men (18.6 \%) consisted of patients with polytrauma and unsatisfactory outlook to life and disease severity. The second group included patients with combined trauma - 462 people. (32.8 \%) - with a doubtful prognosis for life. The third group - 685 people (48.6 \%) - patients with isolated trauma and pleasant good-effects of treatment. All patients, besides addition to general clinical examination, determine the number of platelets, clotting time, duration of bleeding and studied coagulation (prothrombin index, prothrombin activity trombotest, total fibrinogen, fibrinogen, fibrinogen A, activated recalcification time). State of the venous system of the lower limbs studied using distal ascending phlebography, color Doppler and duplex ultrasonography using SIMENS ACUSSON X 300.

Results and Discussion. All patients in full volume underwent prevention of thromboembolic complications through the use of anticoagulants low-molecular weight and required necessary complex kinetic treatment. Cybor in medical dose was administered from the first day of patient's stay in the hospital for 10-14 days postoperative once a day subcutaneously in the abdominal area. For patients with moderate risk and high operational risk (major surgery, age over 40, obesity, serious comorbidities), cybor was administered 5000-7500 IU per day during the patient's stay in the hospital. If you suspect or changes in the availability of venous leg, in patients with a history burdened, conducted dressing elastic stockings and elastic bandaging. Movements during surgery in ankle joints, early activation of patients after surgery, physiotherapy were carried out in all patients. Medicines, that increase venous tone used in the treatment of patients with chronic venous insufficiency. In individuals with subacute and chronic thrombophlebitis of subcutaneous veins performed surgical prophylaxis of thromboembolic complications. Crossectomy performed in 9 (1.9\%) patients, as a first step before surgery.

Key words: thromboembolism; injuries; prevention. 


\section{Л. Ю. ИВАЩУКํㅡ, Д. В. ОСАДЧУКํㅡ, Б. М. МАЙКА²}

гВУз “Тернопольский государственный медицинский университет имени И. Я. Горбачевского”,

Тернопольская городская коммунальная больница скорой помощи²

\section{ПУТИ ПРОФИЛАКТИКИ ТРОМБОЭМБОЛИЧЕСКИХ ОС.ОЖНЕНИЙ У ТРАВМАТОЛОГИЧЕСКИХ БО.ЛЬНЫХ}

Цель работы: проанализировать эффективность профилактики тромбоэмболических осложнений у травматологических больных, перенесших оперативные вмешательства.

Материалы и методы. Обследовались пациенты травматологического отделения Тернопольской городской коммунальной больницы скорой помощи. В 2016 г. поступило 1410 больных разных возрастных категорий, которые были разделены на 3 группы. Первую группу - 263 человека (18,6 \%) - составили больные с политравмой и неблагоприятным прогнозом для жизни из-за тяжести заболевания. Во вторую группу входили пациенты с сочетанной травмой - 462 больних (32,8 \%) - с сомнительным прогнозом для жизни. Третья группа - 685 пациентов $(48,6$ \%) - больные с изолированной травмой и благоприятным исходом лечения. Всем пациентам, кроме общеклинических обследований, определяли количество тромбоцитов, время свертываемости крови, длительность кровотечения и у всех изучали коагулограмму (протромбиновый индекс, протромбиновую активность, тромботест, общий фибриноген, фибриноген В, фибриноген А, активированное время рекальцификации). Состояние венозной системы нижних конечностей исследовали с помощью дистальной восходящей флебографии, цветной допплерографии и дуплексной ультрасонографии аппаратом SIMENS ACUSSON X 300.

Результаты исследований и их обсуждение. Всем больным в полном объеме была проведена профилактика тромбоэмболических осложнений путем применения антикоагулянтов с низкой молекулярной массой и обязательным комплексом кинетерапии. Цибор в лечебной дозе назначали с 1-х суток пребывания пациента в стационаре по 10-14-е сутки послеоперационного периода один раз в сутки подкожно в область живота. Для пациентов с умеренным риском и высоким операционным риском (большие вмешательства, возраст старше 40 лет, ожирение, серьезные сопутствующие заболевания) цибор назначали по 5000-7500 ME в сутки в течение пребывания пациента в стационаре. При подозрении или наличии изменений со стороны венозного русла ног у больных с отягощенным анамнезом проводилось одевание эластичных чулок и эластичное бинтование. Субоперационные движения в голеностопных суставах, ранняя активизация больного после операции, лечебная физкультура осуществлялись во всех пациентов. Венотоники (детралекс, флебодиа и др.) применяли в комплексном лечении пациентов с хронической венозной недостаточностью. У лиц с подострым и хроническим тромбофлебитом подкожных вен осуществляли хирургическую профилактику тромбоэмболических осложнений. Кроссэктомию выполнено у 9 (1,9 \%) пациентов как первый этап перед оперативным вмешательством.

Ключевые слова: тромбоэмболизм; травматизм; профилактика.

Отримано 12.01.17 